\title{
Pengembangan Modul Fisika Pokok Bahasan Hukum Newton bagi Anak Berkebutuhan Khusus (Tunanetra) Di Kelas Inklusi SMA/MA Kelas X
}

\author{
Fitriany Yudistia R dan Winarti \\ Pendidikan Fisikan, Fakultas Sains dan Teknologi UIN Sunan Kalijaga Yogyakarta \\ Surat-e: fitriayudistia@ymail.com
}

\begin{abstract}
Siswa tunanetra SMA Muhammadiyah 4 Yogyakarta, MAN Maguwoharjo dan SMAN I Sewon belum memiliki sumber belajar mandiri berupa modul Braille khususnya pada materi Hukum Newton. Berdasarkan kenyataan ini maka dibutuhkan sebuah sumber belajar yang didesain khusus bagi siswa tunanetra di kelas Inklusi yakni modul Braille pada pokok bahasan Hukum Newton.

Telah dilakukan penelitian yang bertujuan untuk: (I) mengembangkan modul fisika pokok bahasan Hukum Newton untuk siswa tunanetra SMA/MA kelas X sebagai sumber belajar mandiri, (2) mengetahui kualitas modul fisika Braille materi Hukum Newton untuk siswa tunanetra SMA/MA kelas X, (3) mengetahui respon siswa terhadap modul fisika Braille yang telah dikembangkan.

Penelitian ini merupakan penelitian $R \& D$ dengan model prosedural yang mengadaptasi dari pengembangan perangkat model 4-D, yakni Define, Design, Develop, and Disseminate. Instrumen penelitian berupa angket kualitas modul yaitu menggunakan skala Likert yang dibuat dalam bentuk checklist. Instrumen untuk siswa berupa angket respon siswa yaitu menggunakan skala Guttman yang dibuat dalam bentuk checklist. Modul dinilai kualitasnya oleh 3 ahli materi, I ahli media, dan 2 guru fisika SMA/MA. Kelayakan modul berdasarkan respon siswa pada uji coba terbatas sebanyak 2 siswa dan uji coba luas sebanyak 8 siswa.

Hasil penelitian berdasarkan penilaian dari ahli materi, ahli media dan guru fisika SMA/MA modul memiliki kategori sangat baik (SB). Persentase keidealan menurut ahli materi adalah 87,88\%; persentase keidealan menurut ahli media adalah 90,00\% dan persentase keidealan menurut guru Fisika SMA/MA adalah 75,00\%. Respon siswa terhadap modul fisika Braille pada uji coba terbatas diperoleh persentase $97,22 \%$; sedangkan pada uji coba luas diperoleh persentase $89,58 \%$. Hasil penelitian ini menunjukkan bahwa modul layak dijadikan sebagai salah satu sumber belajar mandiri bagi siswa tunanetra.
\end{abstract}

Kata kunci: modul, huruf Braille, inklusi, tunanetra

\section{Pendahuluan}

Undang-undang Republik Indonesia Nomor 20 tahun 2003 tentang Sistem Pendidikan Nasional memberikan warna lain dalam penyediaan pendidikan bagi anak berkelainan. Pada penjelasan pasal I5 tentang pendidikan khusus disebutkan bahwa pendidikan khusus merupakan pendidikan untuk peserta didik yang berkelainan atau peserta didik yang memiliki kecerdasan luar biasa yang diselenggarakan secara inklusif atau berupa satuan pendidikan khusus pada tingkat pendidikan dasar dan menengah. Pasal inilah yang memungkinkan terobosan bentuk pelayanan pendidikan bagi anak berkelainan berupa penyelenggaraan pendidikan inklusif.

Terkait pasal di atas, muncul istilah pendidikan luar biasa dan trend pendidikan inklusi untuk memenuhi kebutuhan pendidikan Anak Berkebutuhan Khusus (ABK). Pendidikan inklusi inilah diselenggarakan secara inklusif di Sekolah Inklusi atau berupa satuan pendidikan khusus pada tingkat pendidikan dasar dan menengah. 
Melalui pendidikan inklusif, anak berkelainan dididik bersama-sama anak normal lainnya untuk mengoptimalkan potensi yang dimilikinya. Hal ini dilandasi oleh kenyataan bahwa di dalam masyarakat terdapat anak normal dan anak berkelainan yang tidak dapat dipisahkan sebagai suatu komunitas. Oleh karena itu, anak berkelainan perlu diberi kesempatan dan peluang yang sama dengan anak normal untuk mendapatkan pelayanan pendidikan di sekolah terdekat.

Kehadiran anak berkebutuhan khusus di sekolah reguler dalam proses belajar mengajar akan berdampak pada proses perubahan kelas, selain dihadapkan pada kelas klasikal, guru juga diberikan tanggung jawab untuk membimbing, mendidik dan mengajar keberagaman anak berkebutuhan khusus. Ketunanetraan, berdampak pada sulitnya mengatur proses belajar mengajar.

Berdasarkan hasil observasi dan wawancara dengan siswa tunanetra di beberapa SMA/MA Inklusi di Yogyakarta, ditemukan banyak keluhan-keluhan yang dikemukakan oleh para siswa siswi tunanetra. Menurut mereka, fisika merupakan mata pelajaran yang membutuhkan pemahaman lebih, karena selain banyak ilustrasi gambar dan simbolsimbol juga banyak rumus-rumus yang digunakan. Dengan keterbatasan indera penglihatannya, siswa mengalami kesulitan untuk memahami gambar dan simbol-simbol karena siswa hanya mampu membayangkan saja. Guru hanya menjelaskan materi di papan tulis dengan metode ceramah. Namun, terkadang guru mendekati siswa tunanetra dan mendiktekan materi yang disampaikan, itu pun jika ada waktu senggang untuk mendiktekkan. Sering kali siswa tunanetra tidak mencatat secara keseluruhan materi yang disampaikan dikarenakan keterbatasan waktu dalam proses pembelajaran, bahkan catatan mereka hanya berupa lembaran kertas yang berceceran karena tidak menyatu dengan catatan fisika lainnya.

Selain itu, masih belum tersedia sumber belajar bagi siswa tunanetra yakni modul Braille khususnya materi Hukum Newton di SMA Muhammadiyah 4 Yogyakarta, MAN Maguwoharjo dan SMAN I Sewon.

Bertolak dari permasalahan inilah, peneliti memberikan suatu alternatif penggunaan media cetak bagi siswa tunanetra, yaitu pengembangan modul fisika pokok bahasan Hukum Newton bagi anak berkebutuhan khusus (tunanetra) SMA/MA kelas X.

Lee dkk. (2003) dalam Pariawan Lutfi Ghazali merekomendasikan penggunaan media cetak dengan huruf Braille dan gambar timbul dalam pendidikan pada penyandang tunanetra untuk melengkapi informasi yang diberikan secara lisan (audio). Setiap alat bantu pendidikan memiliki keterbatasan, sehingga pendekatan multi-strategi dalam pendidikan perlu dilakukan dengan menggunakan berbagai alat bantu (Yahya, B., 2000:30). Menurut Lee et all (2003) dalam Pariawan Lutfi Ghazali, kelebihan media cetak ini adalah dapat segera dilakukan pengulangan informasi dan dapat memberikan informasi tentang bentuk suatu benda dan media cetak merupakan alat bantu pendidikan yang mampu menginformasikan materi pendidikan dengan lengkap bagi penyandang tuna netra (Purwanta, 2003).

Tujuan penelitian ini adalah: (I) Mengembangkan modul fisika pokok bahasan Hukum Newton untuk siswa tunanetra SMA/MA kelas $\mathrm{X}$ sebagai sumber belajar mandiri. (2) Mengetahui kualitas modul fisika pokok bahasan Hukum Newton untuk siswa tunanetra yang telah dikembangkan. (3) Mengetahui respon siswa terhadap modul fisika pokok bahasan Hukum Newton untuk siswa tunanetra.

\section{Metode Penelitian}

Penelitian ini merupakan penelitian pengembangan (research and development/R\&D) yang berorientasi pada produk. Penelitian ini menggunakan metode penelitian pengembangan model prosedural yang mana model ini bersifat deskriptif, menunjukkan langkah-langkah yang harus diikuti untuk menghasilkan produk. Prosedur dalam penelitian ini mengadaptasi pada pengembangan perangkat model 4-D (four $D$ model) yang dikemukakan oleh Thiagarajan, Semmel, dan Semmel (1974) dalam Trianto (2010:93). Model ini terdiri dari 4 tahap pengembangan, yaitu Define, Design, Develop, and Disseminate.

Modul dinilai kualitasnya oleh 3 ahli materi, I ahli media, dan 2 guru fisika SMA/MA. Aspek yang diuji meliputi aspek kualitas isi, metode penyajian, kebahasaan, kegrafikan, format modul, organisasi modul dan konsistensi modul. Instrumen penelitian berupa angket kualitas modul yaitu menggunakan skala Likert yang dibuat dalam bentuk checklist.

\section{Hasil Dan Pembahasan}

Hasil penelitian pengembangan yang pertama adalah tersusunnya Modul Fisika bagi Anak Berkebutuhan Khusus (Tunanetra) pokok bahasan Hukum Newton Untuk kelas Inklusi SMA/MA kelas X. Modul ini berisikan daftar isi, deskripsi modul, standar kompetensi dan kompetensi dasar, petunjuk penggunaan modul, uraian materi, contoh soal, glosarium dan daftar pustaka. Karena modul yang dikembangkan untuk siswa tunanetra, maka modul di cetak dengan huruf Braille dan gambar timbul. 
Sebelum modul dinilai kualitasnya, terlebih dahulu modul di validasi oleh validator. Hasil validasi adalah lembar masukan dari validator. Hasil revisi dari validator dihasilkan modul II yang kemudian modul dapat dinilai kualitasnya oleh para ahli dan guru fisika SMA/MA.

Hasil pengembangan yang kedua adalah kualitas modul fisika yang ditinjau berdasarkan penilaian 3 orang ahli materi, I orang ahli media, dan 2 orang guru fisika SMA/MA kelas X dengan mengisi angket kualitas modul fisika serta memberikan masukan dalam pengembangan modul.

Hasil penilaian modul fisika Braille dari dua aspek penilaian mendapat skor rata-rata modul fisika Braille sebesar 38,67. Dengan demikian modul fisika Braille dikategorikan sangat baik menurut ahli materi.

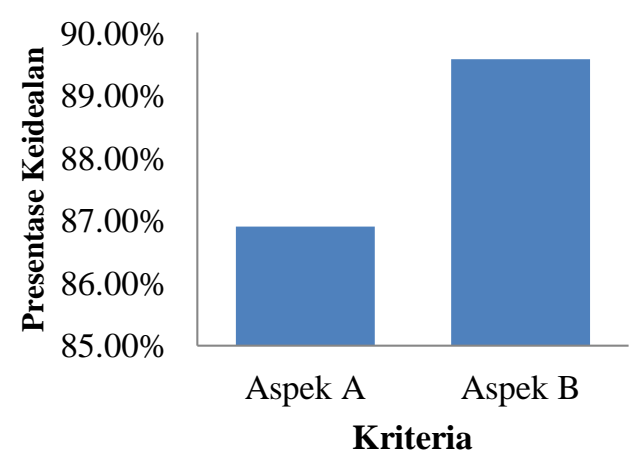

Diagram I . Diagram Batang Presentase Keidealan Modul Fisika Braille Materi Hukum Newton dari Ahli Materi

Diagram I menunjukkan hasil penilaian kualitas modul menurut ahli materi pada tiap aspek. Sedangkan presentase keidealan secara keseluruhan untuk ahli materi didapat nilai sebesar $87,88 \%$. Hal ini dikarenakan masih ada beberapa hal yang perlu direvisi seperti memisahkan gaya berat, gaya normal dan gaya tegangan tali menjadi sub bab-sub bab.menambahkan contoh aplikasi Hukum Newton dalam kehidupan sehari-hari; merubah gaya tegang tali menjadi gaya tegangan tali; memberikan nomer pada setiap persamaan dengan mengacu pada tata tulis sistem SI; memberikan keterangan judul pada grafik/gambar; memberikan penegasan istilah/definisi pada besaran yang dipakai; memperbaiki gambar yang sesuai dengan konsep dan memperbaiki penulisan daftar pustaka.

Hasil penilaian ahli media dari enam aspek penilaian memiliki skor rata-rata 54,00. Dengan demikian modul fisika Braille dikategorikan sangat baik menurut ahli media. Pada saat penilaian ahli media pun terdapat beberapa revisi terkait kaidah penulisan menurut EYD dan merubah uji kompetensi menjadi contoh-contoh soal yang dilengkapi dengan pembahasannya, sehingga presentase keidealan menurut ahli media sebesar 90,00\% yang dapat ditunjukkan oleh diagram 2 berikut.

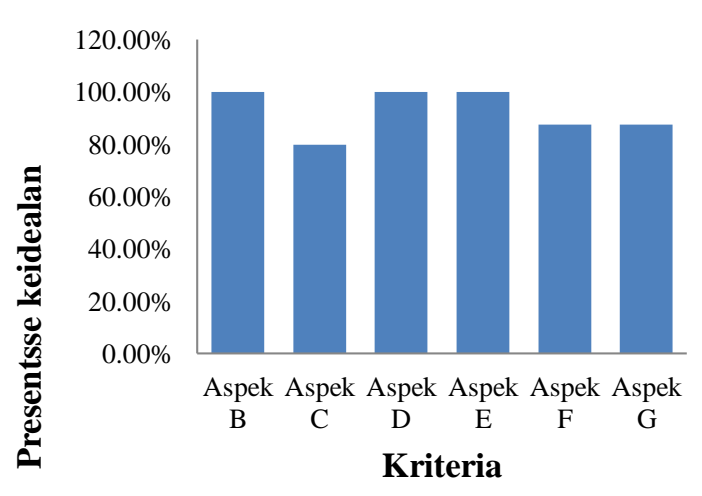

Diagram 2. Diagram Batang Presentase Keidealan Modul Fisika Braille Materi Hukum Newton dari Ahli Media

Penilaian modul fisika Braille secara keseluruhan oleh guru fisika SMA/MA dikategorikan sangat baik (SB) dengan skor rata-rata 36,00. Presentase penilaian kualitas modul untuk masing-masing aspek yaitu aspek kualitas isi $75,00 \%$, aspek metode penyajian $75,00 \%$, aspek kebahasaan 75,00\% dan aspek kegrafikan 75\%. Berikut ini disajikan diagram 3 presentasi keidealan penilaian dari guru fisika SMA/MA.

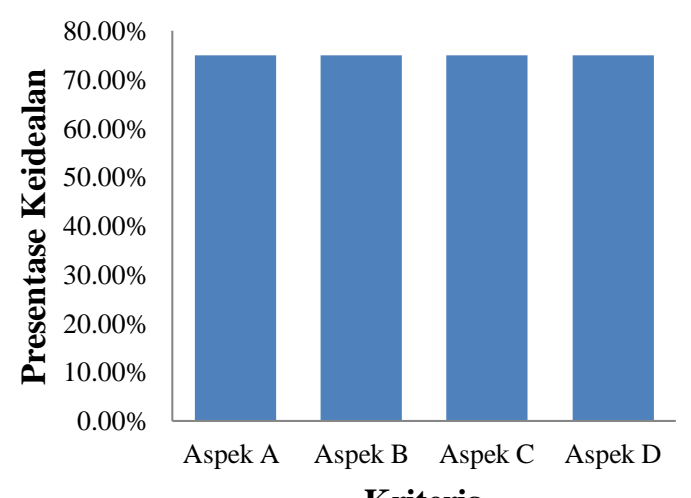

Diagram 3. Diagram Batang Presentase Keidealan Modul Fisika Braille Materi Hukum Newton dari Guru Fisika SMA/MA 
Dari diagram presentase ideal tiap aspek di atas menunjukkan bahwa presentasi keidealan secara keseluruhan menurut guru fisika SMA/MA adalah sebesar 75\%. Hal ini dikarenakan masih terdapat beberapa masukan dari para guru dengan menambahkan prasyarat yang ditujukan kepada peserta didik.

Setelah merevisi modul II berdasarkan masukan ahli materi, ahli media dan guru fisika, maka didapat modul III yang selanjutnya akan diujicobakan kepada siswa dalam uji coba terbatas. Hasil analisis dari uji coba terbatas didapat skor rata-rata 17,50 dengan presentase aspek secara keseluruhan adalah $97,22 \%$ dengan presentasi tiap-tiap aspek seperti diagram 4 .

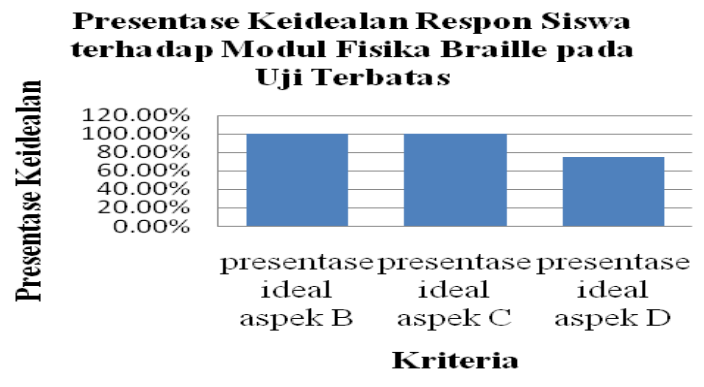

Diagram 4. Diagram Presentase Keidealan Respon Siswa terhadap Modul Fisika Braille pada Uji CobaTerbatas

Pada tahap uji coba terbatas terdapat beberapa masukan dari siswa yakni perlu memperhatikan penulisan, karena satu titik timbul salah sedikit saja akan merubah makna tulisan itu sendiri; akan lebih jelas lagi bila ditambahkan alat peraga tiga dimensi; akan lebih baik bila tidak hanya bab Hukum Newton saja. Akan tetapi materi yang lain juga. Karena di sekolah saya belum ada modul fisika, terlebih pada setiap tahun ada fenomena-fenomena baru. Jadi akan lebih baik bila di Braille kan bab atau materi lain.

Dari masukan di atas, penulis hanya menindaklanjuti masukan yang pertama, yaitu memperbaiki tulisan yang salah cetak. Masukan yang ke dua dan ke tiga tidak ditindaklanjuti karena jika menambahkan alat peraga dan menambah materi yang lain, maka akan menambah biaya yang cukup besar dan memakan waktu penelitian yang cukup lama serta tidak sesuai dengan tujuan penelitian.

Setelah menindaklanjuti masukan dari uji coba terbatas, maka didapatkan draft IV yang selanjutnya diujicobakan kepada siswa dalam uji coba luas.

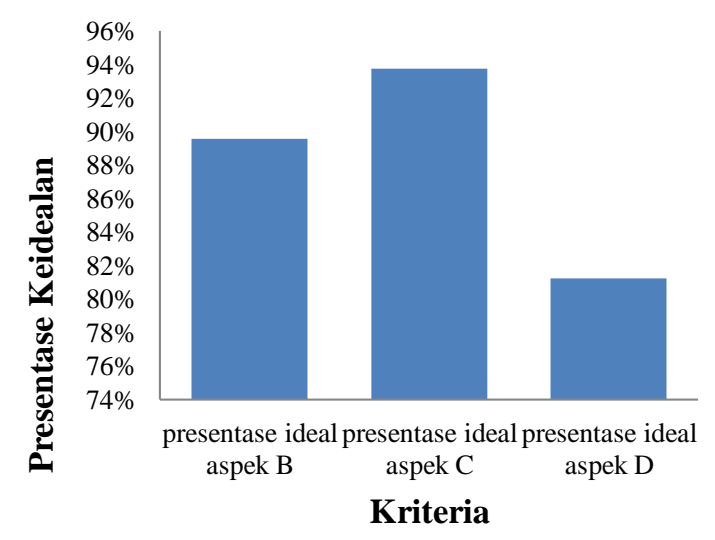

Diagram 5. Diagram Presentase Keidealan Respon Siswa terhadap Modul Fisika Braille pada Uji Coba Luas

Diagram 5 di atas menunjukkan hasil respon siswa terhadap modul fisika Braille pada uji coba luas. Tampak bahwa dari tiga aspek penilaian skor rata-rata 16,13 dengan presentase aspek secara keseluruhan adalah 89,58\%.

Skor rata-rata dan presentase respon siswa pada uji coba terbatas lebih tinggi dibandingkan presentase respon siswa pada uji coba luas dikarenakan pada uji coba terbatas setiap siswa diberi modul satu persatu sehingga mereka dapat membaca secara maksimal. Sementara itu pada uji coba luas penulis hanya menyetak tiga buah modul sehingga siswa harus bergantian untuk membaca modulnya. Selain itu terdapat beberapa respon siswa bahwa tulisan Braille dalam modul ada yang terhapus dikarenakan cetakan timbulnya sudah tertekan/terhapus oleh siswa yang sebelumnya.

Saat uji coba luas, terdapat beberapa masukan dari para siswa. Masukan tersebut antara lain: akan lebih baik bila ditambahkan alat peraga dan masih ada beberapa kata yang terhapus. Kemungkinan tulisan timbul tertekan, sehingga ada satu atau dua titik yang tidak timbul lagi. Masukan dari siswa pada saat uji coba luas hanya masukan ke dua yang ditindaklanjuti. Masukan pertama tidak ditindaklanjuti dengan alasan keterbatasan waktu penelitian dan tidak sesuai dengan tujuan penelitian.

Setelah menindaklanjuti masukan-masukan saat uji coba luas, maka didapat modul $\mathrm{V}$ yaitu produk akhir dari modul fisika Braille pokok bahasan Hukum Newton.

\section{Ucapan Terima Kasih}

Terimakasih kepada Program Studi Pendidikan Fisika dan Universitas Islam Negeri Sunan Kalijaga Yogyakarta yang telah memfasilitasi dalam melakukan penelitian ini. 


\section{Kepustakaan}

Djemari Mardapi. (2004). Penyusunan Tes Hasil Belajar. Program Pascasarjana Universitas Negeri Yogyakarta.

Mohammad Effendi. (2006). Pengantar Psikopedagogik Anak Berkelainan. Jakarta: Bumi Aksara.

Nusa Putra. (20I I). Research \& Development. Jakarta: PT Raja Grafindo Persada.

Pariawan Lutfi Ghazali. Pengembangan Buklet Sebagai Media Pendidikan Kesehatan Reproduksi Pada Remaja Tuna Netra. Jurnal Kedokteran Dan Kesehatan Indonesia.

Sari Rudiyati. (2005). Pengembangan Materi Dan Alat Bantu Pembelajaran Anak Tunanetra Disekolah Terpadu/Inklusi. UNY: Jurnal Pendidikan Khusus Vol. I No. 2 November 2005.

Sudirdjo, Sudarsono \& Siregar, Eveline. (2007). Mozaik Teknologi Pendidikan. Jakarta: Nuansa.

Sugiyono. (2009). Metode Penelitian Kuantitatif, Kualitatif, dan $R \& D$. Bandung: Alfabeta.

Suparno \& Purwanto, H. (2007). Pendidikan Anak Berkebutuhan Khusus. Jakarta: Direktorat Jendral Pendidikan Dasar dan Menengah.

Tim Puslitjaknov. (2008). Metode Penelitian Pengembangan. Jakarta: Pusat Penelitian Kebijakan dan

Trianto. (2010). Model Pembelajaran Terpadu, Konsep, Strategi dan Implementasinya dalam Kurikulum Tingkat Satuan Pendidikan. Jakarta: PT Bumi Aksara.

Yahya, B. (2000). Use of Electronic Media in Health Promotion: Is It Cost Effective?. Buletin Kesihatan Masyarakat. Isu Khas 2000. Ministry of Health. Malaysia: Health Education Division. 